\title{
PENGEMBANGAN MEDIA PEMBELAJARAN IPA POKOK BAHASAN MATA MANUSIA BERBASIS ANDROID
}

\author{
Arif Billah $^{1}$, Sarwanto ${ }^{2}$ \\ ${ }^{1}$ Institut Agama Islam Salatiga, Jl. Lingkar Salatiga Km. 2 Pulutan, Sidorejo, Salatiga, Indonesia 50716 \\ E-mail: arifbillahbadr@iainsalatiga.uns.ac.id \\ ${ }_{2}^{2}$ Program Studi Pendidikan Fisika, Fakultas Keguruan dan Ilmu Pendidikan, Universitas Sebelas Maret, Jl. Ir. Sutami \\ No.36A, Jebres, Surakarta, Indonesia 57126 \\ Email : sarwanto@fkip.uns.ac.id
}

Diajukan: 1 Agustus 2020; Diterima: 2 September 2020; Diterbitkan: 30 Oktober 2020

\begin{abstract}
Abstrak: Studi lapangan dan literatur merekomendasikan bahwa dibutuhkan media pembelajaran pokok bahasan mata manusia yang menyajikan tujuan pembelajaran, materi, evaluasi dan penilaiannya, serta mendukung terjadinya proses pembelajaran mandiri, interaktif, dan menyenangkan. Metode penelitian pengembangan ini menggunakan langkah-langkah: potensi dan masalah, pengumpulan data, desain produk, validasi desain, revisi desain, uji coba produk, revisi produk, uji coba pemakaian, revisi produk, dan produksi masal. Produk penelitian ini adalah aplikasi android "Alat Optik Mata Manusia". Karakteristik produk ini adalah: (1) memuat tujuan pembelajaran, materi, simulasi, latihan soal, dan evaluasi; (2) menu materi memuat: bagian-bagian mata, proses melihat, dan gangguan mata; (3) terdapat lima submenu simulasi yang interaktif dan komunikatif; (4) materi diuraikan melalui teks dan gambar full color; (5) terdapat evaluasi dengan penilaiannya; (6) dapat digunakan secara mandiri dan dapat mengulang-ulang materi yang diinginkan; dan (7) dapat digunakan dimanapun dan kapanpun. Kriteria kelayakan produk adalah "sangat baik" dengan nilai 4,60; kriteria kepraktisan "sangat baik" dengan nilai 4,51; dan kriteria keefektivan "tinggi" dengan n-gain 0,76 sedangkan nilai rerata aktivitas siswa adalah $89,02 \%$ dengan kriteria "sangat baik".
\end{abstract}

Kata Kunci: media pembelajaran, IPA, alat optik, mata manusia

\begin{abstract}
Field studies and literature recommend that learning media for the subject of the human eye is needed that presents learning objectives, materials, evaluations and assessments, and supports an independent, interactive, and fun learning process. This development research method uses the following steps: potential and problems, data collection, product design, design validation, design revision, product testing, product revision, usage testing, product revision, and mass production. The product of this research is the android application "Human Eye Optical Instrument". The characteristics of this product are: (1) contains learning objectives, materials, simulations, practice questions, and evaluations; (2) the material menu contains: parts of the eye, the process of seeing, and eye disorders; (3) there are five interactive and communicative simulation submenus; (4) the material is described through text and full color images; (5) there is an evaluation with the assessment; (6) can be used independently and can repeat the desired material; and (7) can be used anywhere and anytime. The product eligibility criteria are "very good" with a score of 4.60; practicality criteria "very good" with a score of 4.51; and the effectiveness criterion is "high" with an $n$-gain of 0.76 while the average value of student activity is $89.02 \%$ with the criteria of "very good".
\end{abstract}

Keywords: learning media, science, optical instruments, human eye

\section{Pendahuluan}

Salah satu Materi Pokok mata pelajaran Ilmu Pengetahuan Alam (IPA) kelas VIII sekolah menengah pertama adalah mata manusia. Materi pokok ini untuk memenuhi Kompetensi Dasar (KD) pada kurikulum 2013 yang berbunyi: "Menganalisis sifat cahaya, pembentukan bayangan pada bidang datar dan lengkung, serta penerapanya untuk menjelaskan proses penglihatan manusia, mata serangga, dan prinsip kerja alat optik".

Kompetensi Dasar adalah pengetahuan, keterampilan, dan sikap minimal yang harus dicapai oleh peserta didik untuk menunjukkan bahwa peserta didik tersebut telah mampu menguasai standar kompetensi yang telah ditetapkan. Hal ini menjadikan guru Sekolah Menengah Pertama kelas VIII berkewajiban mendesain pembelajaran sedemikian rupa sehingga siswanya mampu untuk menganalisis 
dan memahami penerapan konsep sifat cahaya dan pembentukan bayangan pada proses penglihatan manusia.

Berdasarkan hasil studi lapangan di SMP Negeri 8 Salatiga terkait pembelajaran IPA pokok bahasan penglihatan manusia menunjukkan bahwa proses pembelajaran membutuhkan media pembelajaran yang layak, parktis, dan efektif dalam: (1) menyajikan tujuan pembelajaran dan materi yang sesuai dengan kompetensi dasar; (2) menampilkan konsep abstrak seperti jalannya sinar saat terjadinya proses penglihatan mata terhadap sebuah objek; (3) menampilkan struktur dan fungsi bagian mata manusia; (4) menampilkan perbedaan mata normal dengan mata yang mengalami gangguan penglihatan; dan (5) menyajikan kuis, latihan soal, dan evaluasi dalam rangka uji kompetensi siswa. Selain itu, media pembelajaran ini diharapkan dapat mendukung terjadinya proses pembelajaran: (6) mandiri; (7) interaktif dan (8) menyenangkan.

Tujuan penelitian ini adalah mengembangkan media pembelajaran berbasis android pokok bahasan "mata manusia" yang layak, praktis, dan efektif.

\section{Landasan Teori}

Proses pembelajaran tidak dapat dipisahkan dari pemilihan model, strategi, metode, dan media pembelajaran yang tepat (Qamariah, Jumadi, Senam, \& Wilujeng, 2017). Secara umum, media pembelajaran dapat didefinisikan sebagai alat bantu proses belajar mengajar. Segala sesuatu yang dapat dipergunakan untuk merangsang perhatian, pikiran, perasaan, kemampuan, dan ketrampilan pebelajar sehingga dapat mendorong terjadinya proses belajar.

Salah satu solusi alternatif yang relevan saat ini adalah pemanfaatan teknologi informasi dan komunikasi sebagai basis pengembangan media pembelajaran tersebut. Pemanfaatan teknologi komunikasi sangat diperlukan untuk pendidikan dalam proses belajar mengajar (Ulfa, Sugiyarto, \& Ikhsan, 2017). Media pembelajaran berbasis komputer mendukung siswa termotivasi dalam belajar, lebih kreatif dan bahagia (Billah \& Widyatmoko, 2018).

Perangkat komunikasi berbasis perpaduan antar seluler dan internet menjadi tren yang memiliki kemungkinan untuk dapat digunakan sebagai mobile learning (Astra,
Nasbey, \& Nugraha, 2015). Menurut Said dkk (2018), pembelajaran berbasis teknologi mobile learning memungkinkan siswa untuk dengan mudah memperoleh informasi dan materi pembelajaran secara efektif dan efisien dengan hasil peningkatan kompetensi peserta didik yang signifikan. Dampak bagi para guru adalah mereka dapat mengontrol informasi, materi, dan tes kepada peserta didik dari mana saja dan kapan saja (Said, Kurniawan, \& Anton, 2018).

Saat ini, pemilihan android sebagai software sistem operasi dalam mengembangkan mobile learning dirasa sangat tepat, hal ini dikarenakan penggunaan mobile learning berbasis android dapat: (1) meningkatkan kemampuan berpikir tingkat tinggi siswa (Mardiana \& Kuswanto, 2017); (2) meningkatkan kreativitas dan pencapaian kognitif siswa (Ulfa et al., 2017); (3) meningkatkan kemandirian belajar siswa dan pemahaman konseptual (Arista \& Kuswanto, 2018); (4) menjadikan pembelajaran lebih menarik dan tidak monoton (Widyastuti, Soegiyanto, \& Yusup, 2018); (5) meningkatkan kompetensi representasi diagram dan argumentatif dalam pembelajaran fisika (Liliarti \& Kuswanto, 2018); selain itu, (6) aplikasi berbasis android dapat difungsikan untuk belajar, menjawab kuis, untuk melihat galeri gambar dan video serta untuk melakukan permainan puzzle (Setiawan, Handojo, \& Hadi, 2017).

Namun demikian, integrasi yang efektif dari teknologi seluler ke dalam proses belajar mengajar hanya dapat berhasil dengan metode pengajaran yang tepat. Penggunaan teknologi dalam lingkungan pembelajaran dengan bimbingan dan pemantauan yang tepat memungkinkan pebelajar untuk memperoleh keterampilan yang dibutuhkan untuk pembelajaran sepanjang hayat (Marzouki, Idrissi, \& Bennani, 2017).

\section{Metode Penelitian}

Metode yang digunakan dalam penelitian ini research and development. Langkah-langkah penelitian mengikuti metode R\&D Sugiyono (2016) yang dijelaskan pada gambar 1.

Produk dari penelitian ini adalah software aplikasi android yang berjudul "Alat Optik Mata Manusia" yang telah melalui serangkaian tahapan validasi dan uji coba. 


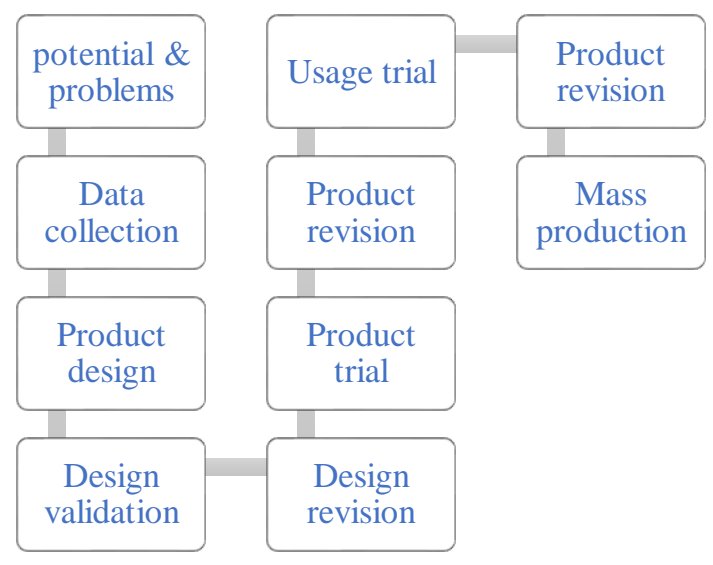

Figure 1. Research steps (Sugiyono, 2016)

Penilaian kelayakan dan kepraktisan produk dilakukan oleh ahli materi, ahli media, dan praktisi (guru). Efektivitas produk diukur dengan menggunakan faktor gain (n-gain) dalam penguasaan konsep mata manusia, dan adanya aktivitas positif dari siswa yang ditunjukkan melalui hasil observasi.

Penelitian ini dilakukan di SMP Negeri 8 Salatiga. Subjek uji coba pemakaian pada penelitian ini adalah siswa kelas VIII berjumlah 30 siswa. Subyeknya adalah homogen. Variabel terikat dalam penelitian ini adalah penguasaan konsep siswa terhadap pokok bahasan mata manusia dan variabel bebasnya adalah penggunaan produk penelitian pengembangan berupa media pembelajaran pokok bahasan mata manusia berbasis android.

Kriteria keberhasilan penelitian ini adalah: (1) Produk yang dikembangkan dikatakan layak jika hasil validasi dari validator memperoleh kriteria minimal "cukup"; (2) Produk yang dikembangkan dikatakan efektif jika nilai $n$-gain dalam kategori "sedang" dan adanya aktivitas positif dengan kriteria minimal "baik"; serta (3) Produk yang dikembangkan dikatakan praktis jika hasil validasi dari validator memperoleh kriteria minimal "cukup".

\section{Hasil Dan Pembahasan}

Pada tahap awal, potensi dan masalah sebagai pijakan penelitian ini didapat dari studi lapangan dan studi literatur. Studi lapangan dilakukan dengan teknik wawancara, dokumentasi, dan kuesioner di SMP Negeri 8 Salatiga. Sedangkan studi literatur dilakukan dengan cara literasi sumber-sumber bacaan tentang: kurikulum 2013, media pembelajaran, dan pembuatan aplikasi berbasis android. Tahap ini menghasilkan kesimpulan bahwa media pembelajaran berbasis android pokok bahasan mata manusia yang layak, praktis, dan efektif dibutuhkan siswa sekolah menengah pertama khususnya siswa SMP Negeri 8 Salatiga.

Tahap pengumpulan data berisi pembuatan konsep, pengumpulan, dan pemilihan materi mata manusia untuk dijadikan sebuah aplikasi android. Pada tahap ini juga dilakukan: (1) identifikasi standar kompetensi; (2) analisis dan penetapan kompetensi dasar; (3) perumusan indikator keberhasilan; (4) pembuatan butir tes acuan patokan; (5) pengembangan strategi pembelajaran; dan (6) pengembangan dan pemilihan media pembelajaran. Materi-materi tersebut selanjutnya disusun menjadi story board sebelum didesasin menjadi aplikasi android bernama "Alat Optik Mata Manusia". Hasil desain ini selanjutnya disebut desain awal.

Desain awal divalidasi oleh ahli materi, ahli media, dan praktisi. Catatan saran yang diberikan oleh validasi mengenai produk digunakan dasar untuk merevisi produk. Produk yang telah melalui tahap validasi dan revisi selanjutnya diujicobakan pada skala terbatas. Aplikasi produk penelitian ini mengalami revisi sebanyak tiga kali sebelum uji coba pemakaian atau uji coba skala luas. Uji coba skala luas melibatkan 30 siswa SMP Negeri 8 Salatiga.

Catatan saran perbaikan produk yang diberikan oleh validator dan responden pada saat validasi dan tahapan-tahapan uji coba dijadikam bahan masukan dan revisi akhir produk pengembangan sebelum tahap produksi masal. Produk akhir merupakan produk yang telah tervalidasi ahli materi, ahli media, dan praktisi, serta mengalami uji coba luas. Produksi masal hasil pengembangan dilakukan dengan mengunggah file software android apk ke google play store.

Tampilan halaman awal produk hasil pengembangan tampak pada gambar 2. Menu utama produk berisi: (1) tujuan pembelajaran, (2) materi, (3) simulasi, (4) latihan soal, dan (5) evaluasi. Tampilan menu ini ditunjukkan pada gambar 3. 


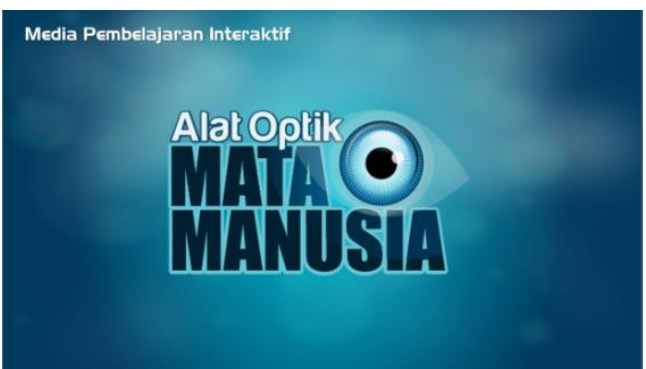

Gambar 2. Tampilan halaman awal

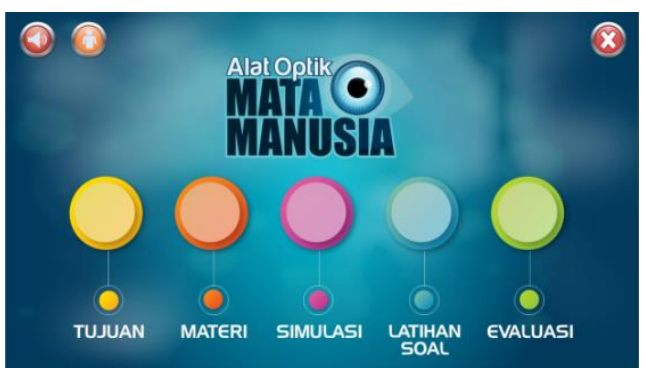

Gambar 3. Tampilan halaman menu

Gambar 4 merupakan tampilan halaman tujuan pembelajaran. Menu Tujuan pembelajaran berisi: kompetensi dasar dan indikator pencapaian kompetensi. Gambar 5 adalah tampilan awal halaman materi. Menu materi berisi: bagian-bagian mata, proses melihat, dan gangguan mata. Gambar 6 adalah tampilan awal halaman simulasi. Menu simulasi berisi simulasi: nama bagian mata, fungsi bagian mata, pembentukan bayangan, rabun jauh, dan rabun dekat. Gambar 7 adalah tampilan awal halaman latihan soal, dan gambar 8 adalah tampilan awal halaman evaluasi.

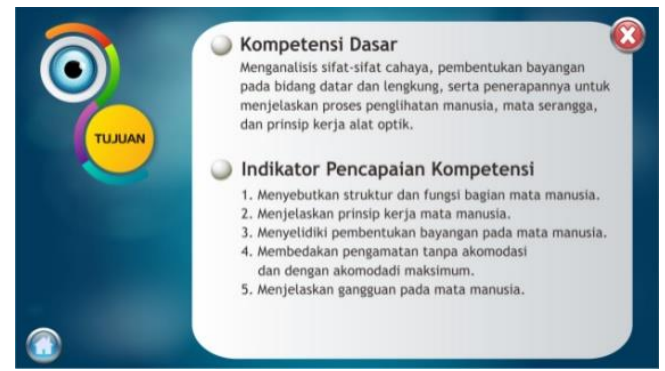

Gambar 4. Tampilan awal halaman tujuan

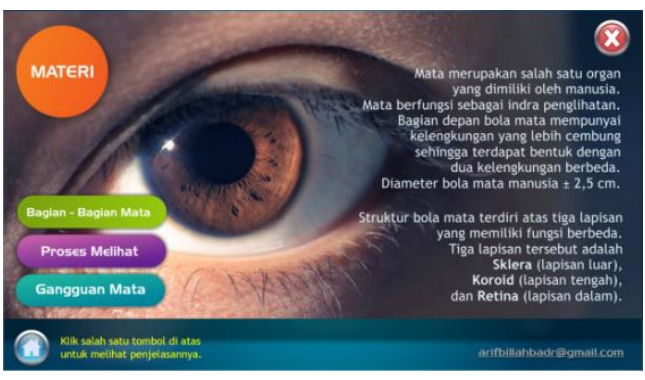

Gambar 5. Tampilan awal halaman materi

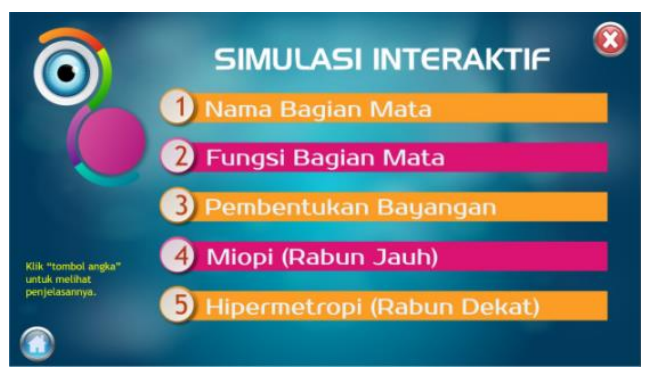

Gambar 6. Tampilan awal halaman simulasi

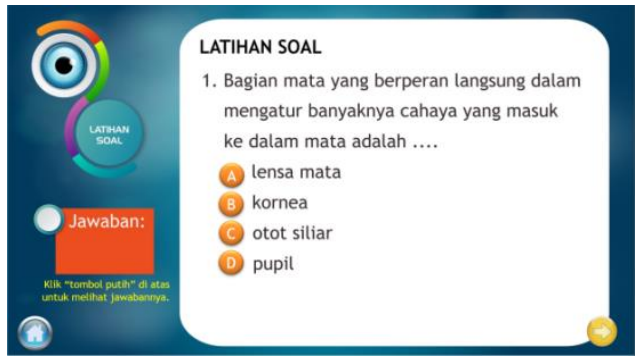

Gambar 7. Tampilan awal halaman latihan soal

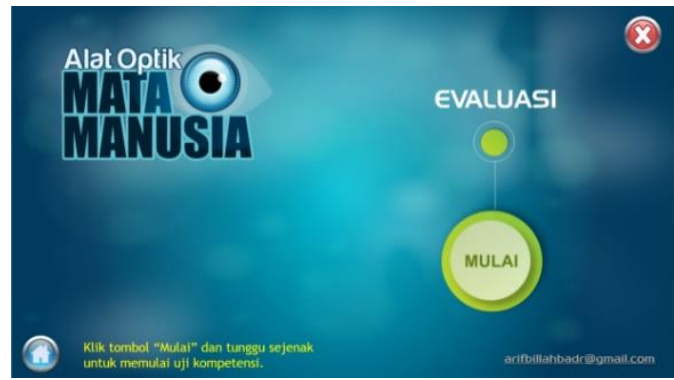

Gambar 8. Tampilan awal halaman evaluasi

Gambar 9 merupakan tampilan logo aplikasi yang telah terunggah di google playstore. Tahap evaluasi produk pengembangan menghasilkan empat macam data, yaitu (1) data hasil penilaian ahli (materi, media dan guru), (2) data hasil uji coba terbatas tahap I, (3) data hasil uji coba terbatas tahap II, dan (4) data hasil uji coba lapangan. Penilaian dari pernyataan kualitatif dari ahli materi, ahli 
media, guru, dan siswa kemudian dikonversikan menjadi nilai skala lima, dengan hasil konversi seperti pada Tabel 1. Data nilai hasil konversi skor kemudian diolah untuk mengetahui kategori kualitatif dari produk

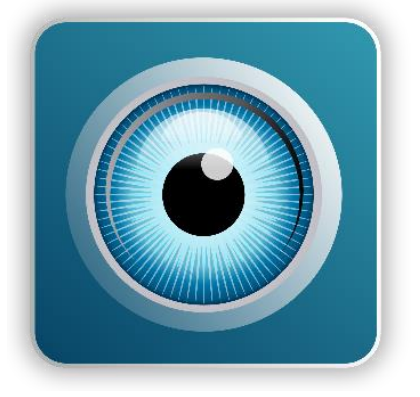

Gambar 9. Tampilan logo produk

Tabel 1. Hasil konversi skor penilaian

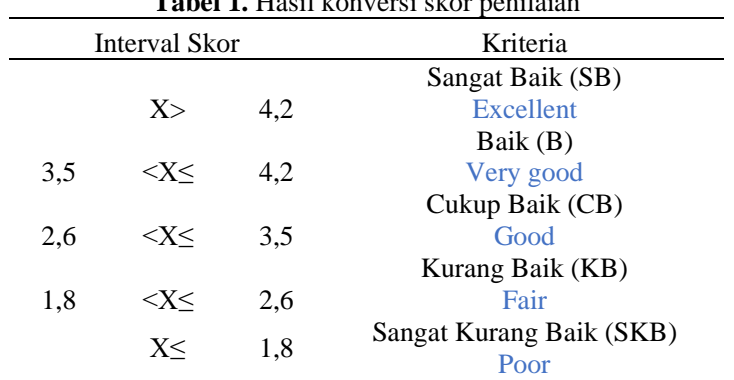

Keterangan: $\mathrm{X}=$ Skor Aktual

Data uji kelayakan oleh ahli materi dan guru terhadap produk hasil pengembangan ditunjukkan oleh Tabel 2, sedangkan, data uji kepraktisan oleh ahli media dan guru terhadap produk hasil pengembangan ditunjukkan oleh Tabel 3.

Tabel 2. Data hasil uji kelayakan produk

\begin{tabular}{cccc}
\multicolumn{4}{c}{ Tabel 2. Data hasil uji kelayakan produk } \\
\hline Aspek & Validator & Nilai & Kriteria \\
\hline Kelayakan & Ahli materi & 4,56 & Sangat baik \\
Isi & Guru & 4,64 & Sangat baik \\
Kelayakan & Ahli materi & 4,58 & Sangat baik \\
Penyajian & Guru & 4,60 & Sangat baik \\
& & & \\
\hline \multicolumn{2}{c}{ Rerata } & 4,60 & Sangat baik \\
\hline
\end{tabular}

Berdasarkan tabel 2 dan 3 di atas, maka produk hasil pengembangan dapat dikatakan layak dan praktis. Rerata skor hasil uji coba kelayakan adalah 4,60 dengan kriteria "sangat baik" dan rerata skor hasil uji coba kepraktisan produk adalah 4,51 dengan kriteria "sangat baik".

Efektivitas produk diukur dengan menggunakan faktor gain (n-gain) dalam penguasaan konsep mata manusia, dan adanya aktivitas positif dari siswa selama proses pembelajaran yang ditunjukkan melalui observasi. Data hasil penilaian penguasaan konsep siswa terhadap pokok bahasan mata manusia ditunjukkan pada Tabel 4.

Tabel 3. Data hasil uji kepraktisan produk

\begin{tabular}{cccc}
\hline Kriteria & Validator & Nilai & Kriteria \\
\hline Kualitas dan & Ahli Media & 4,34 & Sangat baik \\
kehandalan & Guru & 4,36 & Sangat baik \\
Kemudahan & Ahli Media & 4,44 & Sangat baik \\
Penggunaan & Guru & 4,50 & Sangat baik \\
Desain/bentuk & Ahli Media & 4,68 & Sangat baik \\
Pengaruh & Guru & 4,76 & Sangat baik \\
terhadap & Guru & 4,54 & Sangat baik \\
Individu & & & \\
\hline \multicolumn{2}{c}{ Rerata } & 4,51 & Sangat baik \\
\hline
\end{tabular}

Tabel 4. Data hasil penguasaan konsep siswa

\begin{tabular}{lcc}
\hline $\begin{array}{c}\text { Penguasaan } \\
\text { Konsep }\end{array}$ & Skor & Kriteria \\
\hline Awal & 54 & Cukup baik \\
\hline Akhir & 89 & Baik \\
\hline Faktor gain & 0,76 & Tinggi \\
\hline
\end{tabular}

Tabel 4 di atas menunjukkan nilai rerata yang diperoleh oleh siswa terhadap penguasaan konsep "mata manusia" sebelum menggunakan produk pengembangan media pembelajaran berbasis android adalah sebesar 54 dengan kriteria "cukup baik". Sedangkan nilai rerata yang diperoleh oleh siswa terhadap penguasaan konsep "mata manusia" setelah menggunakan produk pengembangan media pembelajaran berbasis android adalah sebesar 89 dengan kriteria "baik". Data tersebut menghasilkan Ngain sebesar 0,76 dengan kriteria "tinggi". Perubahan signifikan pada peningkatan penguasaan konsep mengenai mata manusia dapat diamati pada gambar 10 .

Data skor aktivitas siswa selama proses pembelajaran dihasilkan melalui observasi pada setiap pertemuan. Data ini digunakan untuk mengetahui respon positif siswa terhadap produk yang dikembangkan. Obeserver melakukan penilaian di lembar observasi sesuai kategori penilaian, yakni sangat baik (A), baik (B), cukup (C), dan kurang (D). Data selanjutnya dikonversi ke dalam bentuk angka, 
diolah, dan dicari nilai rerata dan persentase aktivitas belajar siswa.

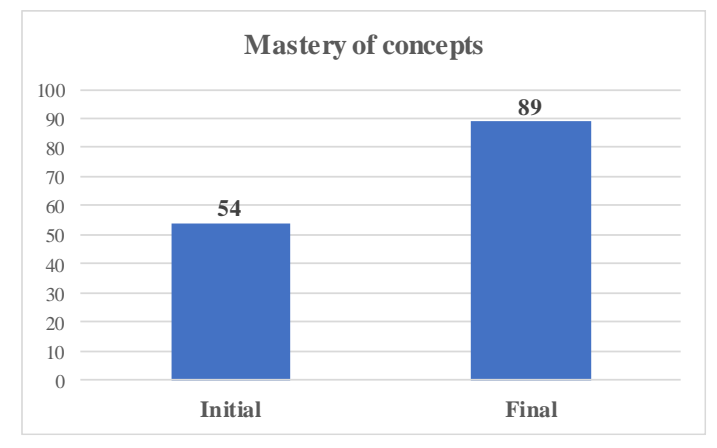

Gambar 10. Perubahan penguasaan konsep

Hasil rerata persentase hasil skor aktivitas siswa ditunjukkan pada tabel 5 .

Tabel 5. Data hasil observasi aktivitas siswa

\begin{tabular}{|c|c|c|c|}
\hline No & $\begin{array}{c}\text { Jenis Aktivitas } \\
\text { Siswa }\end{array}$ & $\begin{array}{c}\text { Rerata } \\
(\%)\end{array}$ & Kriteria \\
\hline 1. & $\begin{array}{l}\text { memperhatikan } \\
\text { penjelasan guru } \\
\text { tentang prosedur } \\
\text { pengoperasian } \\
\text { media pembelajaran } \\
\text { berbasis android } \\
\text { pokok bahasan mata } \\
\text { manusia. }\end{array}$ & 90,4 & $\begin{array}{l}\text { Sangat } \\
\text { baik }\end{array}$ \\
\hline 2. & $\begin{array}{l}\text { antusias membaca } \\
\text { isi materi media } \\
\text { pembelajaran } \\
\text { berbasis android } \\
\text { pokok bahasan mata } \\
\text { manusia. }\end{array}$ & 89,5 & $\begin{array}{l}\text { Sangat } \\
\text { baik }\end{array}$ \\
\hline 3. & $\begin{array}{l}\text { mengerjakan latihan } \\
\text { soal-soal di media } \\
\text { pembelajaran } \\
\text { berbasis android } \\
\text { pokok bahasan mata } \\
\text { manusia. }\end{array}$ & 86,0 & Baik \\
\hline 4. & $\begin{array}{l}\text { mengerjakan } \\
\text { evaluasi di media } \\
\text { pembelajaran } \\
\text { berbasis android } \\
\text { pokok bahasan mata } \\
\text { manusia. }\end{array}$ & 88,4 & $\begin{array}{l}\text { Sangat } \\
\text { baik }\end{array}$ \\
\hline 5. & $\begin{array}{l}\text { melakukan simulasi } \\
\text { dan mengikuti kuis } \\
\text { di dalam media } \\
\text { pembelajaran } \\
\text { berbasis android } \\
\text { pokok bahasan mata } \\
\text { manusia. }\end{array}$ & 90,2 & $\begin{array}{l}\text { Sangat } \\
\text { baik }\end{array}$ \\
\hline 6. & $\begin{array}{l}\text { mengemukakan ide, } \\
\text { pendapat dan }\end{array}$ & 92,2 & $\begin{array}{c}\text { Sangat } \\
\text { baik }\end{array}$ \\
\hline
\end{tabular}

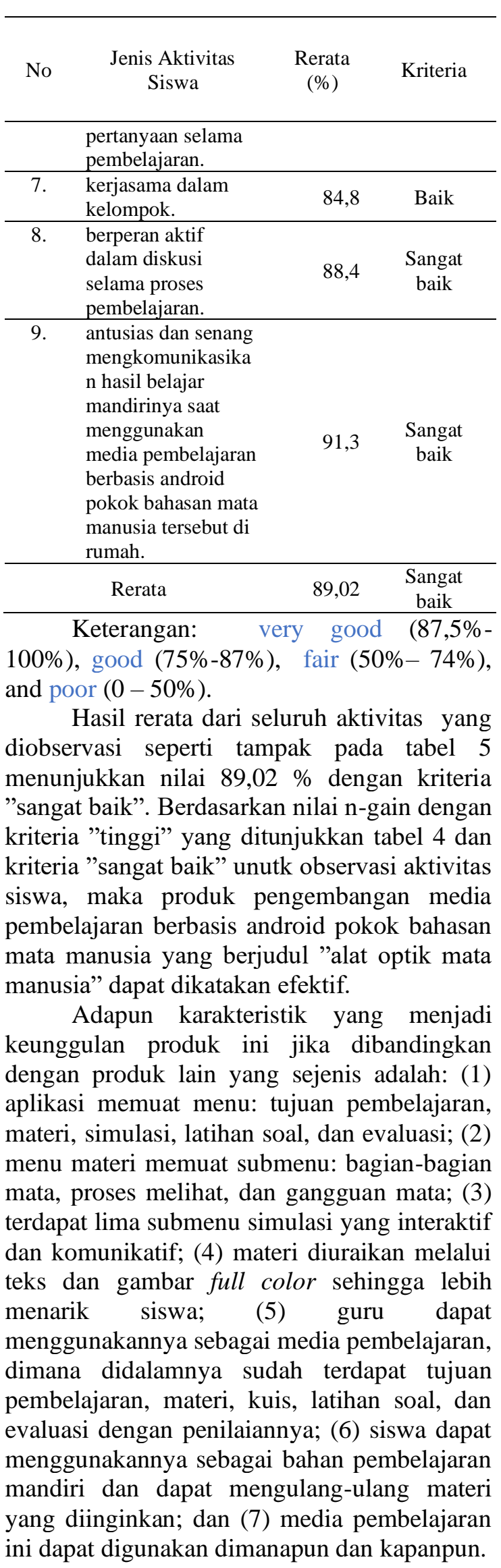


Sedangkan kelemahan produk media pembelajaran berbasis android ini yaitu: (1) belum mampu menampilkan objek secara 3D; (2) untuk smartphone, hanya bisa dijalankan di sistem operasi android; dan (3) tidak ada rekam jejak user sehingga guru tidak tahu apa saja halaman yang telah dibuka user dan bagaimana urutan yang dibukanya.

\section{Kesimpulan}

Penelitian pengembangan ini telah berhasil mengembangkan media pembelajaran berbasis android pokok bahasan "mata manusia" yang layak, praktis, dan efektif. Kriteria kelayakan produk adalah "sangat baik" dengan nilai 4,60; kriteria kepraktisan produk adalah "sangat baik" dengan nilai 4,51; dan kriteria keefektifan produk adalah "tinggi" dengan n-gain 0,76 sedangkan nilai rerata dari seluruh aktivitas yang diobservasi adalah 89,02 $\%$ dengan kriteria "sangat baik".

\section{Daftar Pustaka}

Arista, F. S., \& Kuswanto, H. (2018). Virtual physics laboratory application based on the android smartphone to improve learning independence and conceptual understanding. International Journal of Instruction, 11(1), $1-16$.

Astra, I. M., Nasbey, H., \& Nugraha, A. (2015). Development of an android application in the form of a simulation lab as learning media for senior high school students. Eurasia Journal of Mathematics, Science and Technology Education.

https://doi.org/10.12973/eurasia.2015.1376a

Billah, A., \& Widyatmoko, A. (2018). The Development of Virtual Laboratory Learning Media for The Physical Optics Subject. Jurnal Ilmiah Pendidikan Fisika Al-Biruni, $7(2)$,

153 https://doi.org/10.24042/jipfalbiruni.v7i2.28 03

Liliarti, N., \& Kuswanto, H. (2018). Improving the competence of diagrammatic and argumentative representation in physics through android-based mobile learning application. International Journal of Instruction, 11(3), 106-122.

Mardiana, N., \& Kuswanto, H. (2017). Androidassisted physics mobile learning to improve senior high school students' divergent thinking skills and physics HOTS. In 4th International Conference on Research, Implementation, and Education of
Mathematics and Sciences: Research and Education for Developing Scientific Attitude in Sciences and Mathematics, ICRIEMS 2017 (Vol. 1868). American Institute of Physics

Inc. https://doi.org/10.1063/1.4995181

Marzouki, O. F., Idrissi, M. K., \& Bennani, S. (2017). Effects of Social Constructivist Mobile Learning Environments on Knowledge Acquisition: A Meta-Analysis. International Journal of Interactive Mobile Technologies. https://doi.org/10.3991/ijim.v11i1.5982

Qamariah, Jumadi, Senam, \& Wilujeng, I. (2017). Validity of "hi-Science" as instructional media based-android refer to experiential learning model. In S. S., K. C., W. I., \& A. A.M. (Eds.) (Vol. 1868). Graduate Stud. of Science Education, Yogyakarta State University, Indonesia: American Institute of Physics Inc. https://doi.org/10.1063/1.4995191

Said, K., Kurniawan, A., \& Anton, O. (2018). Development of media-based learning using android mobile learning. Journal of Theoretical and Applied Information Technology, 96(3), 668-676. Retrieved from https://www.scopus.com/inward/record.uri? eid=2-s2.0-

$85042364571 \&$ partnerID $=40 \& \mathrm{md} 5=\mathrm{ab} 615 \mathrm{c}$ 63cd42ff403044ded0310c7731

Setiawan, A., Handojo, A., \& Hadi, R. (2017). Indonesian Culture Learning Application Based on Android. International Journal of Electrical and Computer Engineering (IJECE). https://doi.org/10.11591/ijece.v7i1.pp526535

Sugiyono. (2016). Metode Penelitian Kuantitatif, Kualitatif Dan R\&D. Bandung: Alfabeta. https://doi.org/10.1017/CBO978110741532 4.004

Ulfa, A. M., Sugiyarto, K. H., \& Ikhsan, J. (2017). The effect of the use of android-based application in learning together to improve students' academic performance. In AIP Conference Proceedings. https://doi.org/10.1063/1.4983910

Widyastuti, R., Soegiyanto, H., \& Yusup, Y. (2018). The Development of Geo Smart Based Android for Geography Learning Media on Hydrosphere Material and Its Impact towards Life on Earth. In 1st UPI International Geography Seminar 2017, IGEOS 2017 (Vol. 145). Institute of Physics Publishing. https://doi.org/10.1088/17551315/145/1/012001 